\title{
LAND DEGRADATION AND SOLUTIONS
}

\author{
Do Kieu Anh, Le Do Mai Anh, , Phan Thi Mai Anh, Hoang Tai An, \\ Nguyen Ngoc Minh Anh, Le Thi Tuyet Anh, Nguyen Tran Hiep, Kieu Thi Ngoc Anh, \\ Pham Van Anh, Le Vinh Khanh, Nguyen Thanh Binh
}

Vietnam National University

January 19, 2022

Preprints DOI: https://osf.io/4rbnf

Land plays an indispensable role in the lives of people as well as animals and plants. Over time, land is affected by human activities leading to degradation. The phenomenon of land degradation is very common caused by humans through indiscriminate deforestation, lack of exploitation strategy from the point of view of soil protection and ecological environment protection, shifting cultivation, nomadism... Soil degradation manifests itself in erosion, leaching, chemical degradation, physical and biological degradation. Not only Vietnam but also countries around the world are facing great challenges with the problem of soil pollution because it threatens the living environment of many kinds of organisms (Q.-H. Vuong, 2021).

According to research by scientists, the topsoil is at risk of partially disappearing in the future. The United Nations also warned that about a third of the planet's land resources are being degraded by erosion, pollution, acidification and nutrient depletion. The main cause of this situation is the poor management of the land by humans. The biggest factor of this situation is rooted in human culture (Q. H. Vuong, 2021; Q. H. et al. Vuong, 2018), which is the "exhaustion" of people doing what they do. work of the land for agricultural production. Growing food crops for biofuel production, climate change and simple farming practices are increasing the risk of future food shortages. In addition, there are other direct causes of land degradation, including urbanization, infrastructure development, energy production, mining, etc. (Bộ Tài nguyên và Môi trường, 2019), In addition, there are many other causes of land degradation, both natural and human: tsunamis, earthquakes, storms, floods, deforestation, deforestation and forest degradation (Khuc et al., 2018), inefficient farming, abuse of chemical substances, etc. Soil pollution seriously affects human health and life through inhalation, in addition, it also affects a not a small part to the ecosystem, reducing biodiversity, causing serious consequences for the earth and humanity.

According to statistics, the total natural land area of Vietnam is 33 million hectares, of which 26.1 million hectares are for agriculture, forestry and aquaculture, 3.7 million hectares are used for agricultural purposes. non-agricultural purposes and the remaining 3.3 million hectares have not been put into use. But it is remarkable here that most of the unused areas have been polluted, degraded, desertified or have lost their value due to unreasonable over-exploitation. In the situation of increasing population and strong development of new urban and industrial zones, a large area of non-agricultural and agricultural land bank has been seriously polluted (Báo Nỡ Yêu, 2021). 
Vietnam has up to 9.34 million hectares of fallow land, however, of which about 7.85 million hectares are strongly affected by desertification, most of which is bare land, infertile hills and at risk. severely degraded.... Dry land accounts for $43 \%$ of the world's arable land (Sfarm.vn, 2018). Forest resources have also been significantly reduced, if in 1943 our country had a forest cover rate of $43 \%$, then after many efforts to overcome the situation of deforestation during the past 60 years, the percentage of forest cover now only $37.6 \%$ (December 2006). The loss of forests increases the area of fallow land, which leads to a significant decline of ecosystems, leading to watershed degradation.

The reason is that our country's territory has a high slope; rich flow volume, large speed; upland crops by long-term extensive farming method, burning forests for swidden cultivation, especially watershed forests without vegetation cover, soil erosion, organic matter leaching without measures to foster and supplement organic matter. soil base (mekongfarm, 2018). Soil pollution due to the use of many types of agro-pharmaceuticals in large quantities to protect the quality and quantity of crops, a lot of waste, domestic and industrial wastewater; salinization; poisoning from chemical preparations... the land is gradually degraded (Hùng Chaetomium, 2019). Pollution from industrial activities, mining, farming and poor waste management. Contaminants include metals, cyanides, DDT and other pesticides; PCB...

Faced with the great harm caused by land degradation as a result of land degradation GEF (Global Environment Facility) against land degradation focuses on sustainable land management (SLM) because land degradation is mainly related to desertification and deforestation. The GEF considers that unsustainable agricultural practices along with soil erosion, overgrazing, deforestation, etc. are the main causes of land degradation, all contributing to the decline of ecological services. The Global Environment Facility addresses land degradation by addressing the main causes while finding sustainable solutions. The GEF also focuses on natural resource management in the broader landscape context, enabling investments that focus on effective management of competitive land uses, return of ecosystem services, opportunities to increase investment in SLM through different sources such as: payments for ecosystem services (PES), carbon finance, etc (BBT, 2018), not only need efforts of world organizations but also need the awareness of everyone's cooperation to prevent land degradation: building irrigation systems and proper watering techniques, but this solution is not where Any method can be applied because in many places the techniques and machines are still outdated and have not been applied effectively in protecting degraded land. Or like planting trees, protecting forests, but it takes a few years for trees to grow big enough to hold the land and prevent erosion caused by floods, but besides that, people still exploit trees for wood, leading to progress. The rate of tree planting did not keep up with the cutting progress. People have come up with a series of solutions to apply to life to improve the quality of land, but there are still many solutions that are not really effective and thorough, leading to land degradation that is still happening day by day. abundant in some places, especially those with dense population and poor soil management techniques.

Basic agricultural systems are a major driver of soil and environmental degradation and a significant source of major bio-greenhouse gas emissions. Plowing, inappropriate agricultural practices, combined with deforestation and overgrazing, are the main causes of anthropogenic soil erosion. While much research has focused on agrarian agriculture, in a recent paper, it was shown that protozoan systems cannot be ignored, which may be responsible for the majority of global soil erosion by water (Borrelli et al., 2020). 
However, the underlying driver of all these changes is the growing per capita population due to increasing population, leading to a gradual increase in the demand for protein, fiber and bioenergy. This leads to greater demands and demands for land and further encroachment into marginal land areas.

In addition, market deregulation, which has been a global trend since the 1980s, can lead to the destruction of sustainable land management practices towards monoculture, and may encourage a race downhill. bottom as far as environmental protection is concerned. The vast geographical gap between the demand for consumer goods and the land needed to produce them - in other words, is what causes land degradation and its impact on the environment (Abbas El-Zein, 2018).

Using 3D information processing systems (Vuong, Q. H., 2022; Q. H. Vuong \& Napier, 2014) and semiconductor principles to find effective creative solutions is the key to environmental problems in general and land degradation in particular. Firstly, soil conservation is necessary and urgent to prevent loss of the top layer of soil from erosion, preventing the reduction of fertility in the current alarming state of soil degradation. Secondly, efforts are needed to manage forests and plan for reforestation as deforestation in Paraguay is believed to have decreased by $65 \%$ within two years of the enactment of the 2004 No Deforestation Law. Curb industrial farming, limit plowing, let the land rest (Phạm Văn Đồng, 1964). Thirdly, to diversify soil organisms, implement active mineralization measures as well as increase the use of organic fertilizers for arable land and soil protection, must change human activities such as: farms, cattle grazing, indiscriminate mining,... (Phạm Văn Đồng, 1964). Fourthly, whether industrial waste or domestic waste, effective waste treatment is one of the most effective ways to limit soil pollution, reduce the use of non-biodegradable materials, only It is necessary to switch to reusable cloth bags, thereby reducing plastic waste into the environment, indirectly protecting the land (Phạm Văn Đồng, 1964). Finally, education is the key to reducing the problem of soil pollution, we need to show people the bad effects of our actions on land degradation. It is necessary to urgently develop more specific and practical regulations in: selection of arable land, reclamation, cultivation, fertilization, construction of water-retaining structures and keeping soil color suitable for each region. (Phạm Văn Đồng, 1964).

\section{REFERENCES:}

Abbas El-Zein. (2018). On dangerous ground: land degradation is turning soils into deserts. The Conversation. https://theconversation.com/on-dangerous-ground-land-degradation-isturning-soils-into-deserts94100?fbclid=IwAR2E6Fb8v1yhNnb7_IFvuQRH3i5IBFtsd8pczcWP0heWR_jyKN8V3IUqhsI

Báo Nỡ Yêu. (2021). Thực trạng ô nhiễm môi trường đất ở Việt Nam. Nỡ Yêu. https://noyeu.com/thuc-trang-o-nhiem-moi-truong-dat-o-viet-nam/

BBT. (2018). Hoạt động suy thoái toàn cầu. Gef. https://www.gef.monre.gov.vn/vi/linh-vuctrong-tam/suy-thoai-dat/hoat-dong-suy-thoai-dat-toan-cau/

Bộ Tài nguyên và Môi trường. (2019). Vắt kiệt sức đất. Monre.Gov. https://monre.gov.vn/Pages/vat-kiet-suc-dat.aspx

Borrelli, P., Robinson, D. A., Panagos, P., Lugato, E., Yang, J. E., Alewell, C., Wuepper, D., Montanarella, L., \& Ballabio, C. (2020). Land use and climate change impacts on global soil erosion by water (2015-2070). Proceedings of the National Academy of Sciences of the 
United States of America, 117(36), 21994-22001.

https://doi.org/10.1073/pnas.2001403117

Hùng Chaetomium. (2019). 3 nguyên nhân chính khiến đất trồng bị suy thoái.

Nongnghiepthuanthien.Vn. https://nongnghiepthuanthien.vn/3-nguyen-nhan-chinh-khiendat-trong-bi-suy-thoai/?fbclid=IwAR2PskmIQRQKjE49sSU6Ubbnn-

nNgXbH4TcyDS5VH0Zk2UYM9t09jViuFbs

Khuc, Q. Van, Tran, B. Q., Meyfroidt, P., \& Paschke, M. W. (2018). Drivers of deforestation and forest degradation in Vietnam: An exploratory analysis at the national level. Forest Policy and Economics, 90(February), 128-141. https://doi.org/10.1016/j.forpol.2018.02.004

mekongfarm. (2018). Nguyên nhân của sự toái hóa đất do con người gây nên. Mekongfarm. http://mekongfarm.vn/tin-tuc/24/nguyen-nhan-cua-su-thoai-hoa-dat-do-con-nguoi-gaynen?fbclid=IwAR3LYcpsAUJL3XJ3TSRzDjckVDZfyOAHQ7PZBL5oOppiaa-Nvtw637xS5VU

Phạm Văn Đồng. (1964). Chỉ thị 15-TTG ngày 11/02/1964 về chống xói mòn, giữ đất, giữa mầu, giữ nước do thủ tướng chính phủ ban hành. https://thuvienphapluat.vn/van-ban/Tainguyen-Moi-truong/Chi-thi-15-TTg-chong-xoi-mon-giu-dat-giu-mau-giu-nuoc19672.aspx?fbclid=IwAR1KYCOpl9v9KPckSOI4jq1oyFvfO842|4RqcGcyKaNRZ-W8jjeQ-ilCAbE

Sfarm.vn. (2018). Đất trồng bị thoái hóa: thực trạng, nguyên nhân, giải pháp. Sfarm. https://sfarm.vn/dat-trong-bi-thoai-hoa-thuc-trang-nguyen-nguyen-nhan-va-giaiphap/?fbclid=IwAR2BRSQG7Mi2AVYA11YUEJllaGtTH-VBIQ3P4wNM1i4gcxluPkOXCkz5Acl

Vuong, Q. H., et al. (2022). Covid-19 vaccines production and societal immunization under the serendipity-mindsponge-3D knowledge management theory and conceptual framework. Humanities and Social Sciences Communications, 9, 22. Retrieved from: https://www.nature.com/articles/s41599-022-01034-6

Vuong, Q.-H. (2021). Western monopoly of climate science is creating an eco-deficit culture. Economy, Land \& Climate Insight, 11, 1-9. https://elc-insight.org/western-monopoly-ofclimat

Vuong, Q. H. (2021). The semiconducting principle of monetary and environmental values exchange. Economics and Business Letters, 10(3), 284-290. https://doi.org/10.17811/ebl.10.3.2021.284-290

Vuong, Q. H. et al. (2018). Cultural additivity: behavioural insights from the interaction of Confucianism, Buddhism and Taoism in folktales. Palgrave Communications, 4(143). https://doi.org/10.1057/s41599-018-0189-2

Vuong, Q. H., \& Napier, N. K. (2014). Making creativity: the value of multiple filters in the innovation process. International Journal of Transitions and Innovation Systems, 3(4), 294327. https://doi.org/10.1504/ijtis.2014.068306 